\title{
The Effect of Picture and Picture Learning Model towards Science Outcomes for Students with Hearing Impairment in the Class VII
}

\author{
Yaumil Ainin Pradina, Wiwik Dwi Hastuti \\ Universitas Negeri Malang, Indonesia \\ Email : renasaini@yahoo.co.id
}

\begin{abstract}
Learning science would be difficult if it is abstract. This impact on students' learning outcomes, because it make learning activity not absorbed maximally. It happens to all students including students with hearing impairment. The purpose of this study was to know the effect of the picture and picture learning model towards science learning outcomes. This research was quasi-experimental (Quasi Experiment) with the type of time series design. The results showed that there are significant differences between the average value of pretest and post-test. It can be concluded that the learning model picture and picture effected the science learn outcomes for students with hearing impairment in SMPLBN.
\end{abstract}

Keywords: picture and picture learning model, learning outcomes, children with hearing impairment

Education is one of the vehicles to gain knowledge, and all people are required to get an education without exception, with their education will produce a generation who are more competent in their field. Physical, economic conditions, social conditions is not the obstacles to education. This is regulated in Act of RI No. 20 of 2003 on National Education System Article 32 so-called "special education is an education for learners who have difficulties in following the learning process because of physical, emotional, mental, social "(Efendi, 2009).

A student with hearing impairment is a student who has experienced an interruption in hearing. As result, he is in inability to communicate not only in terms of language skills such as reading and writing but also in social adjustment and learning outcomes at school. A student with hearing impairment can develop optimally, it must be understood his needs to be provided with appropriate support.

According to Kustawan (2013) Learning outcomes is the competence or capability obtained learners with special needs after going through of the learning activities. Learners with special needs is successful in his study when he achieve the learning objectives with the minimum completeness criteria set by the teachers/ schools. Meanwhile, according to Oemar (2006) the learning outcome is that if someone has learned to expect a change in behavior, for example from not knowing become knowing and not understanding become understanding.

The main problem in children with hearing loss is a problem of communication. Inability to communicate has a broad impact as follows problem of language skills such as reading-writing, social adjustment and school performance. In order for students with hearing impairment can develop optimally, it must be understood their needs to be provided with appropriate support. In education services for students with hearing impairment, using images and video very helpful to explain the intent and purpose of the material.

According to Pratiwi and Murtiningsih (2013) SLB B is a special school that cater for special needs children with hearing loss. Shape curriculum and teaching aids are stuated with students' needs and condition. The suitable media for them is visual form or by using the language of the lips/hands.

The results of observations about learning science in deaf students of class VII in SMPLBN is less target graduation in learning due to many factors such as the less varied media, monotonous learning models, and low motivation on students. Results SMPLBN VII grade students is still relatively low, especially in IPA learning. For example, in the process of science learning with natural phenomena of biotic and abiotic matter, teachers only explain the material by using the blackboard, so that, learning is less pleasant, student activity is less, student motivation is low and the results of student learning outcomes are also low.

Somad (1996: 34) expresses the characteristics of children with hearing impairment as follows: (1) The characteristics in terms of intelligence. In general, deaf children have normal intelligence or average. Otherwise, the development of intelligence is strongly influenced by the language development so that deaf children will reveal low intelligence (2) characteristics in terms of language and speech. The ability to speak 
different language and deaf children with hearing children, this is due to the development of language is closely related to the ability to hear. (3) characteristics in terms of emotional and social. Deafness may result alienated from society or social rules that apply in the community where he lives. This situation hindered the development of the child's personality toward maturity.

One of the characteristics of deaf students' learning is by using visual senses. This study used a learning model using visual learning media. One model of learning that uses visual learning media is picture and picture learning model. The purpose of this learning model that teachers know more about the capabilities of each student. Students are trained to think logically and systematically, students are helped to learn to think from the viewpoint of a subject to discussion with students in the practice of freedom of thought, the students' motivation to learn is more developed, students are involved in planning and classroom management. One of these models is the picture and picture learning model.

According to Suprijono (2009) picture and picture is a learning strategy that uses images as a medium of learning, learning by using Picture and picture models will allow learners to know something concrete. Meanwhile, according to Ngalimun (2016) picture and picture are a real treat competency information, presentation materials, show the picture of the activities relating to the material, students sort pictures so sistemtic, teachers confirm the order of the picture, teachers instill concept appropriately in teaching materials, inference, evaluation and reflection. Picture and Picture Learning Model in science teaching materials especially for biotic and abiotic natural phenomena is hoped to help a deaf child to describe and argue about the natural phenomena. Therefore, researchers took the title "The Effect of Picture and Picture Instructional Model toward Science Learning Outcomes for The Deaf Student in Class VII SMPLBN".

\section{METHOD}

The research design used in this study was a quasi experimental Design. A quasi-experimental research experiments conducted in the form of treatment is then given to the research subjects are not fully controlled. Quasi-experimental type used is Time Series Design, according to Sugiyono (2012) used for research groups can not be chosen randomly. In the design of this study is only the use of one group just given a pretest to four times in order to determine the stability and clarity of the circumstances before the treated group and given a post-test four times. If the results of pre test given four times are fickle mean the group showed an unstable state. If the pre-test results are not stable, then performed a pre-test to obtain stable results in the group. In this study using deaf students of class VII SMPLBN. They are 6 students in the second semester of the 2015/2016 academic year.

\section{FINDINGS AND DISCUSSION}

\section{Findings}

In this study, a deaf student in class VII SMPLB is 6 students with hearing barriers. Learning by using picture and picture model that aims to enable them to learn. The image given is simple and does not contain other elements. The analysis of research that has been done as follows: a) planning, b) implementation, and c) the data analysis.

In this planning, it was done early stages of observation to the school which was held on 1 March, and has obtained a license to conduct research in the faculty addressed to SMPLBN, after it was compiled about the pre-test and post-test, after composing instruments or about the study and then in validation by subject matter experts and practitioners. The results of the validation instruments and media carried out by an expert practitioner of material later. Obtained a score of validation by subject matter experts was 91 which indicates the value of the validation of $95 \%$ showed that the validation results was very decent.

The relevance of that aspect was points, lesson plans, content, matter, and media in the Picture and Picture learning model interconnected with the ability of students to be measured. A grain of material with the use of the picture and picture learning model correspond to the learning objectives that can attract more active student. The teacher and students interactions were more meaningful and Science learning outcomes would be increased.

The results of the validation studies showed that the media images make improvements in the picture and picture learning model needs to be enlarged to $50 \%$ again. While the results of the validation by expert practitioners score was 79 which showed the results of the validation of $94 \%$, showing that the results of the validation of instruments included in the very decent category. The aspects assessed in this validation was lattice-left, RPP, matter, matter and media in the picture and picture learning model. The results of the validation study to make improvements in the image on the material that was less magnified.

At the pre-test phase, the implementation of treatment, the implementation of the post-test was held on May 2016-17 May 3, 2016. After learning of the pre-test and post-test then do recapitulation useful to determine whether there was an increase learning outcomes thereafter treatment. Table 1 recapitulation of the value of pre-test and post-test. 
Table 1. Descriptive Statistics

\begin{tabular}{|c|c|c|c|c|c|c|c|c|}
\hline & $N$ & Range & Minimum & Maximum & sum & Mean & $\begin{array}{l}\text { Std. } \\
\text { Deviation }\end{array}$ & Variance \\
\hline $\begin{array}{l}\text { Pretest } \\
\text { Posttest } \\
\text { Valid N } \\
\text { (listwis|e) }\end{array}$ & $\begin{array}{l}6 \\
6 \\
6\end{array}$ & $\begin{array}{l}18.00 \\
30.00\end{array}$ & $\begin{array}{l}19.00 \\
58.00\end{array}$ & $\begin{array}{l}37.00 \\
88.00\end{array}$ & $\begin{array}{l}171.00 \\
434.00\end{array}$ & $\begin{array}{l}28.5000 \\
72.3333\end{array}$ & \begin{tabular}{|l|}
8.09321 \\
11.41344
\end{tabular} & $\begin{array}{l}65.500 \\
130.267\end{array}$ \\
\hline
\end{tabular}

Table 2. The Recapitalation Result of Pre-test and Post-test Value

\begin{tabular}{llcc}
\hline No & Name & \multicolumn{2}{c}{ Value } \\
\cline { 3 - 4 } & & Pre-test $(\mathbf{X})$ & Post-Test (Y) \\
\hline 1 & NHL & 19 & 58 \\
2 & AZD & 35,5 & 88,25 \\
3 & AM & 34,25 & 78,75 \\
4 & SR & 19,25 & 64,75 \\
5 & JYD & 27,25 & 66,25 \\
6 & MNM & 37 & 80 \\
\hline
\end{tabular}

Table 3. Wilcoxon Test

\begin{tabular}{lllllll}
\hline No & $\begin{array}{l}\text { Nilai Pre-test } \\
\left(\mathbf{X}_{\mathbf{1}}\right)\end{array}$ & $\begin{array}{l}\text { Nilai Post-test } \\
\left(\mathbf{X}_{\mathbf{2}}\right)\end{array}$ & $\mathbf{( X 2 - X 1 )}$ & Rank & & Tanda \\
\hline 1 & 19 & 58 & & & Positif & Negatif \\
2 & 35,5 & 88,25 & +39 & 1,5 & $+1,5$ & \\
3 & 34,25 & 78,75 & $+52,75$ & 6 & +6 & \\
4 & 19,25 & 64,75 & $+45,5$ & 4 & +4 & \\
5 & 27,25 & 66,25 & +39 & 1,5 & $+1,5$ & \\
6 & 37 & 80 & +43 & 3 & +3 & \\
\hline \multicolumn{7}{c}{ Jumlah } \\
\hline
\end{tabular}

Based on the table 1 , the data obtained with a minimum value of 19.00 pre-test and Post-test minumun value was 58.00. While the maximum value is 37.00 pre-test and post-test maximum value was 88.00 . While the average value of pre test 50 before using model picture and picture at 28.50, while the average value after using model picture and picture at 72.33 .

On the value of the recapitulation of the above, it can be concluded that the results of studying science when pre-test done is very low and when given treatment (tretment) of picture and picture learning model, students can improve learning outcomes for the better again this is evidenced by the implementation of a post-test.

In this study, using statistical hypothesis testing with test nonparametik, by using the Wilcoxon test. Wilcoxon test is a statistical method used to test the difference of two data pairs, it is thus the number of sample data is always as much. Table 3 is the result of the data in the Wilcoxon test.

Based on the calculation of the amount of the absolute value is taken (the smallest) is Tcount $=0$. While the price Ttabel the real level of $\alpha=0.05$ was obtained price Ttable $=2$ means that $\mathrm{T} 0=0<$ Ttabel
$=2$. From the testing criteria have been established, then the price of $\mathrm{T} 0<\mathrm{Ttabel}$, then $\mathrm{H} 0$ rejected. With so it can be concluded there are differences in learning outcomes IPA deaf students of class VII before and after treatment with study model picture and picture.

\section{Discussion}

A deaf child is a child who experienced obstacles in his hearing, so that in the process of interaction either in education or environment of communities of deaf children rely heavily on visual. Zulfah and Biasa (2015) also revealed that the mastery of materials science of deaf children need visual observation according to the characteristics of deaf children who are accustomed to learn visually. Meanwhile, according to Sarmi et al. (2015) related to science subjects, students' understanding of the nature around is still far from the expected.

Learning categorized successful when learning can be understood by the child and meaningful for the future, so that in the learning of deaf children need visual media. One of the media or learning models that form the model of learning visual picture and picture that the media image as a supporter. Hasan 
(2003) revealed the media image is said to be very effectively used in the classroom because it (1) is concrete, more realistic shows the subject matter than the media verbal only, (2) can overcome the limitations of space and time, (3) can be overcome limitations of observation, (4) can clarify a problem in any field and for any age level, so as to prevent misunderstanding, and (5) cheap and easily obtained and used without the need for special equipment.

While Aunurrahman (2009) states that when students participate actively in the learning process, then these students will be easier to understand the material, and will indirectly improve student learning outcomes. Researchers can determine the ability of students in composing images in a sequence, show pictures, provide information and explain the image, indirectly researchers can also determine the ability of students to understand the concept.

The results of deaf children learn science generally the same as a normal child, it's just that deaf children experience limitations in receiving information and understand a concept. To improve the understanding of the concept can be given a project approach which this approach focuses on learning models tailored to the circumstances given by the students.

In addition, according Herlianti (2015) which mengakaji about the execution of science teaching deaf children in classes VI SLB YPPLB Padang. The results showed that science teaching deaf children less than the maximum if not practice or using a supporting medium, such as a picture. Thus, in this study explain without using the media to support science learning outcomes for deaf children less achieve the desired results indirectly learning objectives are not achieved.

While the research conducted by Igirisa and Ismail (2015) which examines the learning outcomes in the wake of space material for deaf students through cooperative learning model type of picture and picture. The results showed that the learning cycle I was $69.14 \%$ with good criteria and excellent got increase reached $88.84 \%$ with the same criteria. 3 students or $60 \%$ of 5 students were given treatment classified as thoroughly studied with a score of 70 in the first cycle, also increased in the second cycle were awarded to five students who also completed treatment in learning outcomes

In this study, it is hoped the picture and picture learning model effect on the results of deaf students in learning science in grade VII SMPLBN.

\section{CONCLUSION AND SUGGESTION}

Based on the results obtained through the Wilcoxon test can be concluded that there is effect of picture and picture learning model toward IPA learning outcomes for students with hearing impairment in the grade VII SMPLBN.

From the development of the picture and picture media, the researcher provide recommendations for teachers and further researchers.

It is necessary to use the media in learning approach. Teachers can use the picture and picture model of learning in all subjects. By using the flannel board media, teachers can disassemble the image with the subject matter or other. For the next researcher, which uses this study of picture and picture learning model is expected to enhance the image and if needed a board that is used as the put the image to be more innovative and interesting. Image provided should be in accordance with the conditions and the ability of the students themselves, using clear images and easily encountered in their neighborhood.

\section{REFERENCES}

Aunurrahman. (2009). Belajar dan Pembelajaran. Bandung : Alfabeta

Efendi, M. (2009). Pengantar Psikopedagogik Anak Berkelainan. Jakarta: Bumi Aksara.

Hasan, H. (2003). Buku Ajar Strategi Belajar Mengajar. Padang: UNP

Herlianti, J. J. (2015). Pelaksanaan Pembelajaran Ipa Bagi Anak Tunarungu. E-JUPEKhu, 4(1).

Igirisa, S. S., \& Ismail, S. (2015). Meningkatkan Hasil Belajar Pada Materi Bangun Ruang Bagi Siswa Tunarungu Melalui Model Pembelajaran Cooperative Tipe Picture And Picture (suatu penelitian yang dilaksanakan di SMPLB Kabupaten Gorontalo). (Doctoral dissertation, UNG).

Kustawan, D. (2013). Analisis Hasil Belajar Program Perbaikan Dan Pengayaan Peserta Didik Berkebutuhan Khusus. Jakarta Timur : PT.Luxima Metro Media.

Ngalimun. (2016). Strategi dan Model Pembelajaran. Yogyakarta : Aswaja pressindo

Oemar, H. (2006). Proses Belajar Mengajar. Bandung : Bumi Aksara

Pratiwi, R. P., \& Murtiningsih, A. (2013). Kiat Sukses Mengasuh Anak Berkebutuhan Khsus. Yogyakarta : AR-RUZ MEDIA.

Sarmi, N. W., Marhaeni, D. A. I. N., Dantes, G. R., \& St, M. (2015). Pengaruh Penggunaan Pendekatan Pembelajaran Kontekstual Berbantuan Media Gambar Terhadap Minat Dan Hasil Belajar Ipa Pada Siswa Kelas V SLBB N Sidakarya. Jurnal Penelitian dan Evaluasi Pendidikan, 5(1). 
Sugiyono. (2012). Metode Penelitian Kuantitatif Kualitatif dan $R \& D$. Bandung : ALFABETA.

Suprijono, A. (2009). Cooperative Learning. Yogyakarta: Pustaka Pelajar.

Zulfah, T. R., \& Biasa, J. P. L. (2015). Pendekatan Proyek Terhadap Hasil Belajar Konsep Energi Pada Anak Tunarungu Kelas II Di SDLB. Jurnal Pendidikan Khusus, 7(3). 